\title{
Postmenopozal Osteoporozda Paraoksonaz 1 L55M ve Q192R Polimorfizminin İlişkisinin Değerlendirilmesi
}

\author{
Evaluation of the Relationship of Paraoxonase 1 L55M and Q192R \\ Polymorphism in Postmenopausal Osteoporosis
}

${ }^{1}$ Merih Özgen, ${ }^{2}$ Didem Turgut Coşan, ${ }^{1}$ Zeliha Atik, ${ }^{3}$ Faruk Saydam, ${ }^{2}$ Emine Çolak, ${ }^{4}$ Ahu Soyocak, ${ }^{5}$ Fulya Doğaner, ${ }_{1}^{1}$ Funda Berkan, ${ }^{6}$ İfan Değirmenci, ${ }^{7}$ Fezan Mutlu

${ }^{1}$ Eskişehir Osmangazi Üniversitesi Tıp Fakültesi, Fiziksel Tıp ve Rehabilitasyon Anabilim Dalı, Eskişehir, Türkiye ${ }^{2}$ Eskişehir Osmangazi Üniversitesi Tıp Fakültesi, Tıbbi Biyoloji Anabilim Dalı, Eskişehir, Türkiye ${ }^{3}$ Recep Tayyip Erdoğan Üniversitesi Tıp Fakültesi, Tıbbi Biyoloji Anabilim Dalı, Rize, Türkiye ${ }^{4}$ İstanbul Aydın Üniversitesi Tıp Fakültesi, Tıbbi Biyoloji ve Genetik Anabilim Dalı, İstanbul, Türkiye ${ }^{5}$ Aksaray Üniversitesi Fen Edebiyat Fakültesi, Biyoteknoloji ve Moleküler Biyoloji Bölümü, Aksaray, Türkiye

${ }^{6}$ Kütahya Sağlık Bilimleri Üniversitesi Tıp Fakültesi, Tıbbi Biyoloji Anabilim Dalı, Kütahya, Türkiye

${ }^{7}$ Eskişehir Osmangazi Üniversitesi Tıp Fakültesi, Biyoistatistik Anabilim Dalı, Eskişehir, Türkiye

\begin{abstract}
Özet: Osteoporoz, toplumda yaygın görünen, kemik mikro mimarisinde bozulma ve düşük kemik kütlesi ile karakterize sistemik bir hastalıktır. Çalışmamızın amacı paraoksonaz (PON1) geninin 584A $>\mathrm{G}(\mathrm{Gln} 192 \mathrm{Arg})$ ve $172 \mathrm{~T}>\mathrm{A}(\mathrm{Leu} 55 \mathrm{Met})$ polimorfizmleri ile postmenopozal osteoporoz ile ilişkisinin olup olmadığını saptamaktır. Eskişehir Osmangazi Üniversitesi Tıp Fakültesi Fiziksel Tıp ve Rehabilitasyon Anabilim Dalı Kliniği'nde takipli 143 postmenopozal osteoporozu olan ve 102 sağlıklı kadın çalışmaya dahil edildi. Çalışma retrospektif olarak planlandı. Genotipler alel-spesifik DNA primeri ve floresan özellikli DNA probu kullanılarak qPCR cihazında (The Applied Biosystems ${ }^{\circledR}$ StepOne ${ }^{\mathrm{TM}}$ ) belirlendi. PON1 584A $>$ G polimorfizminin genotip ve alel frekanslarında gruplar arasında istatistiksel olarak anlamlı bir fark bulunmamıştır $(\mathrm{p}=0.362$ ve $\mathrm{p}=0.318$ ). PON1 172T $>$ A polimorfizminin genotip ve alel frekansları karşılaştırıldığında ise, sağlıklı bireylere göre postmenopozal osteoporozu olanlarda $\mathrm{T}$ alelinin istatistiksel olarak anlamlı derecede yüksek bulunduğu (sırasıyla p<0.001, p<0.001) gözlendi. Çalışmamızda PON1 172T>A(Leu55Met) gen polimorfizmi ile postmenopozal osteoporoz arasında ilişki olduğu gösterildi.
\end{abstract}

Anahtar Kelimeler: Osteoporoz, PON1, gen polimorfizmi

Abstract: Osteoporosis is a systemic disease which is common in society, characterized by bone micro-architecture deterioration and low bone mass. The aim of our study was to determine whether paraoxonase 1 (PON1) gene correlates with 584A>G (Gln192Arg) and 172T>A (Leu55Met) polymorphisms with postmenopausal osteoporosis. A total of 143 postmenopausal osteoporosis and 102 healthy women who were followed up in Eskişehir Osmangazi University Faculty of Medicine, Department of Physical Medicine and Rehabilitation were included in the study. The study was planned retrospectively. Genotypes were identified on the qPCR (The Applied Biosystems ${ }^{\circledR}$ StepOne ${ }^{\mathrm{TM}}$ ) using the allele-specific DNA primer and fluorescent-specific DNA probe. There was no statistically significant difference between the groups in the genotype and allele frequencies of PON1 584A>G polymorphism $(\mathrm{p}=0.362$ and $\mathrm{p}=0.318)$. When the genotype and allele frequencies of $\mathrm{PON1} 172 \mathrm{~T}>\mathrm{A}$ polymorphism were compared, it was observed that $\mathrm{T}$ allele was significantly higher in postmenopausal osteoporosis than healthy subjects $(\mathrm{p}<0.001, \mathrm{p}<0.001$, respectively). PON1 172T>A (Leu55Met) gene polymorphism was associated with postmenopausal osteoporosis in our study.

Keywords: Osteoporosis, PON1, gene polymorphism

ORCID ID of the authors: M.Ö. 0000-0002-8919-968; D.T.C 0000-0002-8488-640; , Z.A. 0000-0001-7111-3529; F.S. 0000-0003-2358-8719; E.Ç. 0000-0002-6293-2909; A.S. 0000-0003-0999-2774; F.D. 0000-0002-6543-8447; F.B. 0000-0001-7531-3704; I.D. 0000-0002-7074-1694; F.M. 0000-0002-9339-4031

Received 01.03 .2019

Accepted 20.03.2019

Online published 20.03.2019

Correspondence: Merih ÖZGEN - Eskişehir Osmangazi Üniversitesi Tıp Fakültesi, Fiziksel Tıp ve Rehabilitasyon Anabilim Dalı, Eskişehir, Türkiye e-mail: mozgen@ogu.edu.tr 


\section{Giriş}

Osteoporoz (OP), kemik mikro mimarisinde bozulma ve düşük kemik kütlesi ile karakterize, kırıklara neden olan sistemik ve metabolik bir kemik hastalığıdır (1). Osteoporoz ve osteoporoza bağlı gelişen kırıklar, mortalite ve morbiditeyi etkileyerek yaşam kalitesinin azalmasına neden olur. Osteoporoz, oluşumunda genetik faktörler ve çevresel etkilerin birlikte rol oynadığ multifaktöriyel hastalıklar grubunda yer alır (2).

Osteoporoz patogenezinde çeşitli çevresel faktörler rol almakla birlikte, genetik risk faktörleri kemik gücünü sağlayan bileșenlerin oluşumunda önemli rol oynar. Genetik faktörler kemik kütlesi ve bileşimini \%50-80 oranında etkiler (3).

Osteoporozda kemik mineral yoğunluğu (KMY) ve osteoporotik kırıklar ile ilişkili farklı genlerin varlığ Osteoporozda paraoksonaz 1 (PON1) gen aktivitesini ölçen ve polimorfizmlerini değerlendiren çalışmalar mevcuttur.

PON, glikoprotein yapıda olup kalsiyum bağımlı ester hidrolaz enzimidir, aynı zamanda arilesteraz aktivitesine sahiptir. İlk olarak 1946 yılında Abraham Mazur tarafından keşfedilen enzim son derece zehirli orgonafosfat tarım ilaci parationun toksik metaboliti paraoksonu (organanofosfat substratı ) hidroliz edebilmesinden dolayı bu ismi almıştır (6).

PON gen ailesi, insanlarda kromozom 7 (q21.22) 'nin uzun kolunda yer almaktadır ve PON1, PON2 ve PON3 olmak üzere 3 üyesi bulunmaktadır. PON1 ve PON3 karaciğerde eksprese edilir ve yüksek yoğunluklu lipoprotein (HDL)'ye bağlı olarak serumda tespit edilebilir. PON2 serumda tespit edilemez, ancak böbrek, testis, karaciğer ve beyin gibi çeşitli dokularda bulunur (7.8). PON1'in düşük-dansiteli lipoprotein (LDL) ve HDL'yi oksidasyona karşı koruduğu ve oksidatif stresi azalttığ1 gösterilmiştir (9).
Osteoporoz ve kardiyovasküler sistem hastalıkları birçok hastalıkta olduğu gibi oksidatif stres temeline sahiptir ve bu iki durum postmenopozal kadınlarda yaygin olarak görülür (10). Lipid peroksidasyon ürünleri oksidatif strese neden olur. $\mathrm{Bu}$ ürünlerin kemik dokuda mineral içeriğini değiştirerek, formasyonu azaltarak, mineralizasyonu inhibe ederek osteoblastların farklılaşmasını engelleyebileceği ve bu yüzden osteoporoza neden olabileceği bilinmektedir. Bir antioksidan olan PON1'in kemik üzerindeki oksidatif stres etkilerini önleyebileceği bildirilmiştir (11-14).

Yaygın bir halk sağlığı sorunu olan osteoporozun, kemik kaybı ile ilişkili genlerinin belirlenmesi, osteoporozun önlenmesi ve tedavisinde yol gösterici olacaktır. Çalıșmamızın amacı PON1 geninin $584 \mathrm{~A}>\mathrm{G}(\mathrm{Gln} 192 \mathrm{Arg})$ ve $172 \mathrm{~T}>\mathrm{A}(\mathrm{Leu} 55 \mathrm{Met})$ polimorfizmleri ile postmenopozal osteoporoz ile ilişkisinin olup olmadığını saptamak ve geliştirilecek osteoporoz tedavi stratejilerine katkı sağlamaktır.

\section{Materyal ve Metod}

Eskişehir Osmangazi Üniversitesi Tıp Fakültesi Fiziksel Tip ve Rehabilitasyon Anabilim Dalı'nda Ocak 2013-Aralık 2014 takipli 143 izole postmenopozal osteoporozu olan ve 102 sağlıklı kadın çalışmaya dahil edildi. Çalışma retrospektif olarak planlandi. Hastaların osteoporoz tanısı kemik mineral yoğunluğu ölçümü, DXA (Hologic QDR 4500 W, Hologic, Inc., Bedford, USA) yöntemi ile lomber omurga ve kalça (femur boynu, trokanter ve Ward üçgeni) bölgeleri değerlendirilerek konuldu. Dünya Sağlik Örgütüne göre kemik dansitesi ortalamas1 2.5 SD altında olanlar osteoporoz olarak değerlendirildi (15).

Çalışmaya dahil edilen gönüllülerin periferal kan örnekleri $10 \mathrm{ml}$ hacimli $1.6 \mathrm{mg} / \mathrm{ml}$ EDTA (Etilendiamintetraasetik asit) içeren tüplere toplandı. Sonrasında her örneğin genomik DNA'ları önceden protokolü açıklanmış olan tuzla çöktürme yöntemi ile EDTA'l1 tüplerdeki lökositlerden izole edildi (16). İzole 
edilen DNA örnekleri genotipleme protokolüne kadar $-20^{\circ} \mathrm{C}$ 'de saklandı.

Genotipler alel-spesifik DNA primeri ve floresan özellikli DNA probu kullanılarak Real-Time PCR cihazında (The Applied Biosystems ${ }^{\circledR}$ StepOne ${ }^{\mathrm{TM}}$ ) tespit edildi. PON1 genindeki Q192R ve L55M polimorfizmleri, Applied Biosystems StepOne System (Applied Biosystems, Kaliforniya, ABD) cihazında TaqMan analizi kullanılarak RealTime PCR protokolü ile genotiplendirildi. $\mathrm{Bu}$ yöntemde genotiplerin ayırt edilmesi 'erime eğrisi analizi' (melting curve analysis) ile gerçekleştirildi. Bunun için PCR'da DNA amplifikasyonun tamamlanmasindan sonra, sıcaklık çok yavaş bir şekilde yükseltilerek her bir örnek için erime eğrisi oluşturuldu. Sicaklık yükseltilmesi sırasında normal dizi ile polimorfizm içeren dizinin ayırımı gerçekleştirilerek, gen polimorfizmleri belirlendi (Tablo 1).

PCR koşulları; ilk denatürasyon $95^{\circ} \mathrm{C}$ 'de 5 dakika, 40 siklus gerçekleştirilecek olan normal denatürasyon basamağ $9^{\circ} 5^{\circ} \mathrm{C}$ de 10 saniye, annealing ve uzama basamağ 1 ise $60^{\circ} \mathrm{C}$ 'de 1 dakika olacak şekilde cihaza programlandi. PCR amplifikasyonu $50 \mathrm{ng} / \mu 1$ genomik DNA, $10 \mathrm{pmol}$ forward/reverse primer, 8 pmol prob, $200 \mu \mathrm{M}$ dNTP, 1X PCR tamponu (Vivantis Technologies, Selangor, Malaysia), $2 \mathrm{mM}$ MgCI2 ve nükleaz içermeyen suyun bulunduğu toplam $20 \mu 1$ reaksiyon reaksiyon karışımı ile gerçekleştirildi.

$\mathrm{Bu}$ işlemler ESOGÜ Tıp Fakültesi Tıbbi Biyoloji Anabilim Dalı'nda çalışmaya katılan araştırmacılarca yapıldı.

Etik kurul onayı Eskişehir Osmangazi Üniversitesi Tıp Fakültesi Etik Kurulu'nun 04.12.2015 tarihli $80558721 / \mathrm{G}-90$ say11 kararı ile alınmıştır.

\section{İstatistiksel Analiz}

İstatistiksel analizler IBM SPSS Statistics 21.0 (SPSS Inc., Chicago, IL, ABD) kullanılarak hesaplandı. Analiz sonuçları, pearson ki-kare, odds oranı (OR) ve \% 95 güven aralığı (CI) ile gösterildi. Tüm $p$ değerleri için $<0.05$ istatistiksel olarak anlamlı Kabul edildi.

Tablo 1. Real-time PCR protokolünde kullanılan primerlerin ve florasan etiketli probların baz dizilimi

\begin{tabular}{|c|c|c|}
\hline Gen Polimorfizmi & Primerler ve Problar & Baz Dizilimi \\
\hline \multirow[t]{4}{*}{ PON1 Q192R (rs662) } & Forward Primer & 5'-CTGAGCACTTTTATGGCACAAATGA-3' \\
\hline & Reverse Primer & 5'-ACCACGCTAAACCCAAATACATCTC-3' \\
\hline & Wild tip Prob & 5'-HEX-ССТАСТТАСААТССТG-BHQ-1-3' \\
\hline & Mutant tip Prob & 5'-FAM-CCCTACTTACGATCCTG-BHQ-1-3' \\
\hline \multirow{4}{*}{$\begin{array}{l}\text { PON1 L55M } \\
(\mathrm{rs} 854560)\end{array}$} & Forward Primer & 5'-ACAACCTGTACTTTCTGTTCTCTTTTCTG-3' \\
\hline & Reverse Primer & 5'-CAGAGCTAATGAAAGCCAGTCCAT-3' \\
\hline & Wild tip Prob & 5'-HEX-AGTATCTCCAAGTCTTC-BHQ-1-3' \\
\hline & Mutant tip Prob & 5'-FAM-CAGTATCTCCATGTCTTC-BHQ-1-3' \\
\hline
\end{tabular}

\section{Bulgular}

Çalışma grubunun genetik dengesini belirlemek amaciyla hem osteporotik hem de sağlıklı kadınların genotip frekansları Pearson Ki-Kare testi ile analiz edilerek HardyWeinberg kuralına uygun olduğu belirlenmiştir. Osteoporotik ve sağlıklı kadınlardaki PON1 Q192R(584A>G) polimorfizminin genotip ve alel frekanslarının karşılaştırılması Tablo 2'de gösterilmiştir.
Ayrica bu polimorfizmin dominant $(\mathrm{AG}+\mathrm{GG}$ vs. AA) ve resesif ( $G G$ vs. $A A+A G$ ) kalitım modellerinin istatistiksel analizi de ayn tabloda ayrıntılı şekilde belirtilmiştir. Atasal genotipe (AA) karş1 AG ve GG genotiplerin frekansları osteoporotik ve sağlıklı kadınlar arasında istatistiksel anlaml bir fark göstermemiştir (Sırasıyla; $\mathrm{p}=0.43$ ve $\mathrm{p}=0.15$ ). Aynı şekilde alel frekansları bakımından da bu iki grup arasında istatistiksel anlamlı bir fark bulunmamıştır $(\mathrm{p}=0.31)$. 
Tablo 2. Osteoporotik ve sağlıklı kadınlardaki PON1 Q192R(584A>G) polimorfizmi genotip ve alel frekanslarının istatistiksel analizi

\begin{tabular}{|c|c|c|c|c|c|c|c|c|c|}
\hline \multirow[t]{2}{*}{ Grup } & \multicolumn{2}{|l|}{ Alel } & \multirow[t]{2}{*}{$p$} & \multirow{2}{*}{\multicolumn{2}{|c|}{$\begin{array}{l}\text { OR } \\
(\% 95 \text { CI })\end{array}$}} & \multicolumn{3}{|l|}{ Genotip } & \multirow[t]{2}{*}{$p$} \\
\hline & $\begin{array}{c}A \\
n(\%)\end{array}$ & $\begin{array}{c}G \\
n(\%)\end{array}$ & & & & $\begin{array}{c}A A \\
n(\%)\end{array}$ & $\begin{array}{c}A G \\
n(\%)\end{array}$ & $\begin{array}{c}G G \\
n(\%)\end{array}$ & \\
\hline $\begin{array}{l}\text { Sağlıklı } \\
(\mathbf{n}=102)\end{array}$ & $\begin{array}{l}138 \\
(67.6)\end{array}$ & $\begin{array}{l}66 \\
(32.4)\end{array}$ & \multirow[t]{2}{*}{0.31} & \multirow{2}{*}{\multicolumn{2}{|c|}{$\begin{array}{l}1.21 \\
(0.83-1.77)\end{array}$}} & $\begin{array}{l}48 \\
(47.1)\end{array}$ & $\begin{array}{l}42 \\
(41.2)\end{array}$ & $\begin{array}{l}12 \\
(11.8)\end{array}$ & \multirow[t]{3}{*}{0.36} \\
\hline $\begin{array}{l}\text { Osteoporoti } \\
k(n=143)\end{array}$ & $\begin{array}{l}181 \\
(63.2)\end{array}$ & $\begin{array}{l}105 \\
(36.8)\end{array}$ & & & & $\begin{array}{l}67 \\
(46.9)\end{array}$ & $\begin{array}{l}47 \\
(32.9)\end{array}$ & $\begin{array}{l}29 \\
(20.3)\end{array}$ & \\
\hline \multicolumn{9}{|c|}{ OR (\%95 CI) (G Risk Aleli) } & \\
\hline \multicolumn{2}{|l|}{$\begin{array}{l}\text { Heterozigot } \\
\text { AA vs. AG }\end{array}$} & \multicolumn{2}{|c|}{$\begin{array}{l}\text { Homozigot } \\
\text { AA vs. GG }\end{array}$} & \multicolumn{3}{|c|}{$\begin{array}{l}\text { Dominant } \\
\text { AG+GG vs. AA }\end{array}$} & \multicolumn{2}{|c|}{$\begin{array}{l}\text { Resesif } \\
\text { GG vs. AG+AA }\end{array}$} & \\
\hline \multicolumn{2}{|l|}{$\begin{array}{l}0.80(0.45-1.40) \\
p=0.43\end{array}$} & \multicolumn{3}{|c|}{$1.73(0.80-3.73) p=0.15$} & \multicolumn{2}{|c|}{$1.00(0.60-1.67) p=0.97$} & \multicolumn{2}{|c|}{$1.21(0.83-1.77)$} & $p=0.07$ \\
\hline
\end{tabular}

Osteoporotik ve sağlıklı kadınlardaki PON1 L55M(172T $>$ A) polimorfizminin genotip ve alel frekanslarının istatistiksel analizi ise Tablo 3'de gösterilmiştir. Alel ve genotip frekanslarının ki-kare testi yapıldığında $\mathrm{T}$ alelinin risk aleli olabileceği yönde istatistiksel anlamlı fark bulunmuștur (Sirasiyla $\mathrm{p}<0.001, \mathrm{p}<0.001$ ). $\mathrm{Bu}$ nedenle PON1 L55M polimorfizminin dominant (TT+TA vs. AA) ve resesif (TT vs. TA+AA) modellemesi $\mathrm{T}$ risk aleline göre analiz edilmiştir.

Tablo 3. Osteoporotik ve sağlıklı kadınlardaki PON1 L55M(172T>A) polimorfizmi genotip ve allel frekanslarının istatistiksel analizi

\begin{tabular}{|c|c|c|c|c|c|c|c|c|c|}
\hline \multirow[t]{2}{*}{ Grup } & \multicolumn{2}{|c|}{ Alel } & \multirow[t]{2}{*}{$p$} & \multirow{2}{*}{\multicolumn{2}{|c|}{$\begin{array}{c}\text { OR } \\
(\% 95 \mathrm{CI})\end{array}$}} & \multicolumn{3}{|c|}{ Genotip } & \multirow[t]{2}{*}{$p$} \\
\hline & $\begin{array}{c}T \\
n(\%)\end{array}$ & $\begin{array}{c}A \\
n(\%)\end{array}$ & & & & $\begin{array}{c}T T \\
n(\%)\end{array}$ & $\begin{array}{c}T A \\
n(\%)\end{array}$ & $\begin{array}{c}A A \\
n(\%)\end{array}$ & \\
\hline $\begin{array}{l}\text { Sağlıklı } \\
(n=102)\end{array}$ & $\begin{array}{l}94 \\
(46.1)\end{array}$ & $\begin{array}{l}110 \\
(53.9)\end{array}$ & \multirow[t]{3}{*}{$<0.001$} & \multirow[t]{2}{*}{$\begin{array}{l}0.44 \\
0.64)\end{array}$} & $(0.30-$ & $\begin{array}{l}26 \\
(25.5)\end{array}$ & $\begin{array}{l}42 \\
(41.2)\end{array}$ & $\begin{array}{l}34 \\
(33.3)\end{array}$ & \multirow[t]{3}{*}{$<0.001$} \\
\hline $\begin{array}{l}\text { Osteoporotik } \\
(n=143)\end{array}$ & $\begin{array}{l}188 \\
(65.7)\end{array}$ & $\begin{array}{l}98 \\
(34.3)\end{array}$ & & & & $\begin{array}{l}68 \\
(47.6)\end{array}$ & $\begin{array}{l}52 \\
(36.4)\end{array}$ & $\begin{array}{l}23 \\
(16.1)\end{array}$ & \\
\hline \multicolumn{8}{|c|}{ OR (\%95 CI) (T Risk Aleli) } & & \\
\hline \multirow{4}{*}{\multicolumn{2}{|c|}{$\begin{array}{l}\text { Heterozigot } \\
\text { AA vs. TA } \\
1.83(0.93-3.56) \\
p=0.07\end{array}$}} & \multicolumn{2}{|c|}{ Homozigot } & \multirow{2}{*}{\multicolumn{3}{|c|}{ Dominant }} & \multicolumn{2}{|c|}{ Resesif } & \\
\hline & & & \multicolumn{2}{|c|}{ TT+TA vs. AA } & & \multicolumn{2}{|c|}{ TT vs. TA+AA } & \\
\hline & & \multicolumn{2}{|c|}{$3.866(1.92-7.75)$} & \multirow{2}{*}{\multicolumn{3}{|c|}{$\begin{array}{l}2.60(1.42-4.78) \\
p<0.001\end{array}$}} & \multirow{2}{*}{\multicolumn{2}{|c|}{$\begin{array}{r}0.377(0.21-0.65) \\
\boldsymbol{p}<\mathbf{0 . 0 0 1}\end{array}$}} & \\
\hline & & $p<0.00$ & & & & & & & \\
\hline
\end{tabular}

\section{Tartışma}

Osteoporoz düşük kemik mineral yoğunluğu (KMY) ile ilişkilidir ve KMY'i rrksal farklılıklar etkiler (1). Epidemiyolojik çalışmalar aile hikâyesinde osteoporotik kırık olanlarda, osteoporotik kırık riskinin yüksek olduğunu göstermiştir. İkizlerde yapılan çalışmalarda ulaşılan kemik doruk kütlesinin \%70'inde genetik faktörlerin sorumlu olduğu bildirilmiștir. Osteoporozda KMY ve osteoporotik kırıklar ile ilgili farklı genlerin olduğu gösterilmiştir (17-19).
PON1'in osteoporozda aktivitesini ölçen ve gen polimorfizmlerini değerlendiren çalışmalar mevcuttur (20-22). PON1 geninde yaklaşık 200 tek nükleotid polimorfizmi (SNP) tanımlanmıştır (7). Menopoz sonrası kadınlarda, PON1 ve PON2 SNP'lerinin femur boynu veya lomber omurga kemik mineral yoğunluğu ile ilişkili olduğu ve $584 \mathrm{GG}$, $172 \mathrm{TT}$ ve 959CC genotiplerinin kemik kütlesinde azalmadaki risk faktörlerini temsil ettiği bildirilmiştir. Bununla birlikte, PON'un kemik mineral yoğunluğu ile ilişkisinin 
altında yatan moleküler mekanizma henüz tam olarak açıklığa kavuşmamıştır (20).

Osteoporoz gelişiminde lipid oksidasyonunun rolünü gösteren kanıtlar vardır (23). Oksidatif stres, antioksidanlar ve pro-oksidanlar arasındaki dengesizlikten kaynaklanmaktadır (24-26). Oksidatif stres sonucu oluşan reaktif oksijen ürünleri, aşırı miktarda bulunduğunda lipit peroksidasyonuna neden olur (25-29). Oksitlenmiş lipitlerin kemik üzerinde olumsuz etkilere sahip olduğu düşünülmektedir (21). Östrojen oksidatif stresi düzenleme özelliği sayesinde kemik hemostazı ve iskelet büyümesinde etkin rol oynar, ayrıca PON1 seviyelerini düzenleyebilir (30.31). Antioksidanlar oksidatif hasarı kontrol edemediğinde, kardiyovasküler sistem hastalıkları ve osteoporoz gibi hastalıkların geliştiği görülmüştür (27.28). Menopoz sonrası, azalan östrojen nedeniyle hızlı kemik hasarı olur (30). Yapılan çalıșmalar postmenopozal osteoporozda osteoporoz olmayanlara göre antioksidanların azaldığını, peroksidaz düzeylerinin arttığını göstermektedir (10). Lipid peroksidasyonu osteoporoz patogenezinde önemli bir role sahiptir (32). PON1'in lipit peroksidasyon ürünlerini azaltarak antioksidan özellik gösterdiği ve osteoporoz üzerinde potansiyel bir mekanizmaya sahip olabileceği ileri sürülmüştür $(7,8,33)$.

Literatürde PON1 polimorfizminin KMY ile ilişkisinin değerlendirildiği az sayıda çalışmaya rastladık. Yamada ve ark. KMY ile $172 \mathrm{~T}>\mathrm{A}$ ve $584 \mathrm{~A}>\mathrm{G}$ polimorfizmi arasındaki ilişkiyi değerlendirdikleri çalışmada, 172T $>$ A için, TT genotipine sahip olanlarda, A alel taşıyıcılarına göre lomber omurga ve femur boynu KMY'lerinin anlamlı derecede daha düşük olduğunu bildirmişlerdir. 584A $>\mathrm{G}$ için GG genotipine sahip olanlarda, A alel taşıyıcılarına göre femur boynu KMY'sinin anlamlı şekilde daha düşük olduğunu bulmuşlardır (20). Toptaş ve ark.'nın kemik frajilitesi üzerinde PON1 gen polimorfizmi ve paraoksonaz aktivitesinin değerlendirildiği 74 osteoporotik, 121 osteopenik, 79 nonosteoporotik bireyi içeren çalışmada, PON1 55-PON1 192 haplotipleri ile osteopeni grubunda orta güçte bir ilişki olduğu, osteoporoz grubunda ise güçlü bir ilişki bulunduğu bildirilmiştir. Çalışmanın sonucunda PON1 genotiplerinin osteoporoz için yüksek risk nedeni olduğu bildirilmiştir (21). $\mathrm{Bu}$ çalışmalara benzer şekilde çalışmamızda postmenopozal osteoporozun PON1 L55M ile ilişkili olduğu bulunmuştur. Bununla birlikte çalıșmamızın sonuçları postmenopozal osteoporozun PON1 Q192R ile ilişkili olmadığını göstermiştir. Bizim çalışmamızda önceki çalışmalar ile tutarlı olarak 172T alelinin osteoporotik kadınlarda bir risk faktörü olabileceğini düşündürmektedir.

Çalıșmamızdan elde edilen bu sonuçların desteklenebilmesi için farklı popülasyonlarda ve çok sayıda bireyi içeren araştırmalara ihtiyaç olduğu düşünülmüştür.

Osteoporozu olan hastalarda serum PON1 enzim aktivitesi ile KMY arasında ilişki olduğunu bildiren çalıșmalar mevcuttur (21.22). Bizim çalıșmamızda serum PON1 aktivitesinin ölçülmemiş olması çalışmanın eksik yönüdür.

\section{Sonuc}

Toplumda yaygın görünen bir hastalık olan osteoporoz, morbidite ve mortalite nedenidir. Çalışmamızda $\quad 172 \mathrm{~T}>\mathrm{A} \quad$ (Leu55Met) polimorfizmleri ile postmenopozal osteoporozun ilişkili olduğunu gösterdik. Sonuçlarımızın osteoporozla ilgili gen havuzuna katk1 sağlayarak osteoporozun önlenmesi ve geliştirilecek osteoporoz tedavi stratejilerine katkı sağlayacağı kanısındayız. 


\section{KAYNAKLAR}

1. Kanis JA, McCloskey EV, Johansson H, Cooper C, Rizzoli R, Reginster JY, et al. European guidance for the diagnosis and management of osteoporosis in postmenopausal women. Osteoporos Int 2013;24:23-57.

2. Zajickova K, Zofkova I. Osteoporosis: Genetic analysis of multifactorial disease. Endocr Regul 2003;37:31-44.

3. Williams FM, Spector TD. The genetics of osteoporosis. Acta Reumatol Port 2007;32:231-40.

4. Rizzoli R, Bonjour JP, Ferrari SL Osteoporosis, genetics and hormones. $\mathrm{J} \mathrm{Mol}$ Endocrinol 2001;26:79-94.

5. Uitterlinden AG, van Meurs JB, Rivadeneira $\mathrm{F}$, Pols $\mathrm{HA}$ et al. Identifying genetic risk factors for osteoporosis. $J$ Musculoskelet Neuronal Interact 2006;6:16-26.

6. Van Himbergen TM, Van Tits LJH, Roest M, Stalenhoef AFH. The story of PON1: how an organophosphate hydrolyzing enzyme is becoming a player in cardiovascular medicine. Neth J Med 2006;64:34-8.

7. Yilmaz N, Simsek N, Aydin O, Yardan E, Aslan S, Eren E, et al. Decreased paraoxonase 1 , arylesterase enzyme activity, and enhanced oxidative stress in patients with mitral and aortic valve insufficiency. Clin Lab 2013;59:597-604.

8. Eren E, Yilmaz N, Aydin O. High density lipoprotein and it's dysfunction. Open Biochem J 2012;6:78-93.

9. Draganov DI, La Du BN. Pharmacogenetics of paraoxonases: a brief review. Naunyn Schmiedebergs Arch Pharmacol 2004;369:7888.

10. Yilmaz N, Eren E. Homocysteine oxidative stress and relation to bone mineral density in post-menopausal osteoporosis. Aging Clin Exp Res 2009;21:353-7.

11. Mackinnon ES, El-Sohemy A, Rao AV, Rao LG et al. Paraoxonase 1 polymorphisms $172 \mathrm{~T} / \mathrm{A}$ and $584 \mathrm{~A} / \mathrm{G}$ modify the association between serum concentrations of the antioxidant lycopene and bone turnover markers and oxidative stress parameters in women 25-70 years of age. $J$ Nutrigenet Nutrigenomics 2010;3:1-8.

12. Deakin SP, James RW. Genetic and environmental factors modulating serum concentrations and activities of the antioxidant enzyme paraoxonase-1. Clin Sci (Lond) 2004;107:435-47.

13. Eren Z, Kantarci G, Biyikli N, Arikan H, Tuglular S, Ergen A, Isbir T, Akoglu E et al Paraoxonase 1 polymorphisms in patients with primary glomerulonephritis: a singlecenter study in Turkey. Iran J Kidney Dis $2012 ; 6: 181-5$

14. Sztanek F, Seres I, Harangi M, Locsey L, Padra J, Paragh GJ, Asztalos L, Paragh G et al. Decreased paraoxonase 1 (PON1) lactonase activity in hemodialyzed and renal transplanted patients. A novel cardiovascular biomarker in end-stage renal disease. Nephrol Dial Transplant 2012;27:2866-72.

15. Cosman F, de Beur S J, LeBoff M S, Lewiecki EM, Tanner B, Randall S, Lindsay $\mathrm{R}$ et al. Clinician's guide to prevention and treatment of osteoporosis. Osteoporos Int 2014;25: 2359-81.

16. Turgut Cosan D, Colak E, Saydam F, Yazıcı HU, Degirmenci I, Birdane A, Colak E, Gunes $\mathrm{HV}$ et al. Association of Paraoxonase 1 (PON1) Gene Polymorphisms and Concentration with Essential Hypertension. Clinical and Experimental Hypertension 2016;38:602-607

17. Tural S, Kara N, Alaylı G. Genetics of osteoporosis. Turkish Journal of Osteoporosis. 2011;17:100-9.

18. Ozgen M, Cosan DT, Doganer F, Soyocak A, Armagan O, Gunes HV, Degirmenci I, Ozkara GO, Mutlu FS et al. Relationship between plasminogen activator in hibitor type-1 (PAI

1) gene polymorphisms and osteoporosis in Turkish women. Clinics (Sao Paulo) 2012;67:1299-302.

19. Ozgen M, Cosan DT, Doganer F, Soyocak A, Armagan O,Kuzgun S, Aydogan AM, Gunes HV, Degirmenci I, Mutlu FS et al. Is there any association between osteoporotic vertebral fracture and vitamin $\mathrm{K}$ epoxide reductase complex subunit-1 polymorphism in Turkish society? A pilot study. Clinics 2019;74:e739.

20. Yamada $\mathrm{Y}$, Ando F, Niino N, Miki T, Shimokata $\mathrm{H}$ et al. Association of polymorphisms of paraoxonase 1 and 2 genes, alone or in combination, with bone mineral density in community-dwelling Japanese. $J$ Hum Genet 2003;48:469-75.

21. Toptaş B, Kurt Ö, Aydoğan HY, Yaylim I, Zeybek Ü, Can A, et al. Investigation of the common paraoxonase 1 variants with paraoxonase activity on bone fragility in Turkish patients. Mol Biol Rep 2013;40:651924.

22. Verit FF, Celik H,Yazgan P,Erel O,Geyikli I et al. Paraoxonase-1 activity as a marker of atherosclerosis is not associated with low bone mineral density in healthy postmenopausal women. Arch Gynecol Obstet. 2007;275:3539.

23. Mazière C, Salle V, Gomila C, Mazière JC et al. Oxidized low density lipoprotein enhanced RANKL expression in human osteoblastlike cells. Involvement of ERK, NFkappaB and NFAT. Biochim Biophys Acta 2013;1832:1756-64.

24. Almeida M, Han L, Martin-Millan M, O'Brien CA, Manolagas SC et al. Oxidative stress antagonizes Wnt signaling in osteoblast 
precursors by diverting beta-catenin from $\mathrm{T}$ cell factor- to forkhead box O-mediated transcription. J Biol Chem 2007;282:27298305.

25. Xiong J, O'Brien CA. Osteocyte RANKL: new insights into the control of bone remodeling. $J$ Bone Miner Res 2012;27:499-505.

26. Yilmaz N, Kepkep N, Ciçek HK, Celik A, Meram I et al. Relation of parity and homocysteine to bone mineral density of postmenopausal women. Clin Lab 2006;52:4956.

27. Eren E, Ellidag HY, Aydin O, Yılmaz N et al Homocysteine, paraoxonase-1 and vascular endothelial dysfunction: Omnibus viis Romam Pervenitur. J Clin Diagn Res 2014;8:CE01-4.

28. Lobo V, Patil A, Phatak A, Chandra N et al Free radicals, antioxidants and functional foods: Impact on human health. Pharmacogn Rev 2010;4:118-26.

29. Almeida M. Aging mechanisms in bone. Bonekey Rep 2012;1. pii: 102. DOI:10.1038/bonekey.2012.102

30. Weitzmann MN, Pacifici R. Estrogen deficiency and bone loss: an inflammatory tale. J Clin Invest 2006;116:1186-94.

31. Lv H, Ma X, Che T, Chen Y et al. Methylation of the promoter A of estrogen receptor alpha gene in hBMSC and osteoblasts and its correlation with homocysteine. Mol Cell Biochem 2011;355:35-45.

32. Yilmaz N. Relationship between paraoxonase and homocysteine: crossroads of oxidative diseases. Arch Med Sci 2012;8:138-53.

33. Mackness B, Mackness MI, Arrol S, Turkie W, Durrington PN et al. Effect of the human serum paraoxonase 55 and 192 genetic polymorphisms on the protection by high density lipoprotein against low density lipoprotein oxidative modification. FEBS Lett 1998;423: 57-60. 